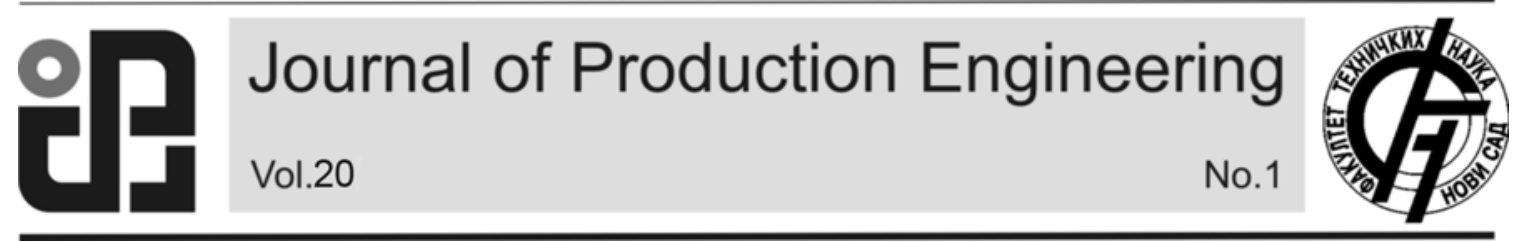

JPE (2017) Vol.20 (1)

\author{
Kovács, Gy.
}

Preliminary Note

\title{
GLOBAL PRODUCTION TENDENCIES - LEAN MANUFACTURING PHILOSOPHY
}

Received: 17 April 2017 / Accepted: 20 May 2017

\begin{abstract}
The growing market globalization, global competition, and complex products results in application of new production processes and methods. Optimization of supply chains results new concepts of value chains. In a competitive market the manufacturing companies have to produce cost effective products which can be realized by minimized production cost and higher effectiveness. These goals can be achieved by the application of Lean manufacturing philosophy. There are lots of Lean methods and tools which can result the improvement of the production line performance. The paper shows global production tendencies, novel supply chain paradigms and summarizes the advantages of application of Lean philosophy.
\end{abstract}

Key words: Lean production, value adding activity, waste, efficiency improvement

Globalna proizvodna tendencija - filozofija LEAN proizvodnje. Sve veća globalizacija tržišta, globalna konkurencija, $i$ kompleksni proizvodi rezultatiraju u primeni novih proizvodnih procesa $i$ metoda. Optimizacija lanaca snabdevanja rezultat je novog koncepta lanaca vrijednosti. U konkurentnom tržištu proizvodne kompanije moraju da proizvode isplative proizvode koji se mogu realizovati uz minimalnei troškove proizvodnje i povećanje efektivnosti. Ovi ciljevi se mogu postići primenom Lean proizvodne filozofije. Postoji mnogo Lean metoda i alata koji mogu biti rezultat poboljšanje performansi proizvodne linije. Ovaj rad pokazuje globalne proizvodne tendencije, nove lance nabavke paradigme i rezimira prednosti primene Lean filozofije.

Ključne reči: Lean proizvodnja, aktivnost dodate vrednost, otpad, poboljšanje efikasnosti

\section{INTRODUCTION}

Changing market environment, market globalization, increasing global competition and fluctuating customer demands require efficient operation of production and logistical processes where the enterprises have to focus on cost reduction and productivity. These global tendencies and novel supply chain conceptions (Lean-, Agile-, Leagile Supply Chains) are introduces in this study.

This research study is very important and actual, because the cost reduction and the improvement of productivity are very important goals of all of manufacturing companies.

Lean manufacturing is a performance-based process used in more and more manufacturing companies to increase competitive advantage in the global market. Nowadays this philosophy is applied in many sectors including automotive, electronics, etc. in order to optimize productivity and costs.

In the study the essence, properties and tools of the Lean philosophy is introduced. Lean manufacturing focuses on cost reduction by eliminating non-value added activities. Originating from the Toyota Production System, many of the tools and methods of Lean manufacturing have been widely used in manufacturing.

\section{GLOBAL PRODUCTION AND LOGISTICAL TENDENCIES}

Fast changing market environment and fluctuating customer demands require efficient operation of production and logistical processes.

The following short description of the global production and logistic tendencies focuses on the changes in the main processes and activities, and reasons behind them.

\subsection{Changes in the customers' demands and product characteristics}

Due to the more unique and rapidly changing customer demands nowadays many industrial sector has completely different strategies than few decades or even few years before. The traditional mass production is replaced by the production of unique products in case of several industries, the variation of finished products that can be chosen by the consumers is almost infinite, and the costumer can freely determine the properties and components of the ordered finished products. For instance in case of a vehicle the finished product variations can reach up to 1000 (a combination of colours, types of engines, other components etc.). At the same time the acceptable delivery time has decreased while the demand for quality has increased. Typically the production of products with shorter lifecycle but more complexity requires novel, more flexible production technologies and logistic processes, and their sales need new business approaches.

\subsection{Changes in production philosophies and production processes}

The traditional mass production is replaced by unique production (or smaller batches), or from the 
philosophical point of view the "Push" approach (make to stock) is replaced by "Pull" approach (make to order) [1].

In case of Push production planning is based on forecasted data (not actual customer demand), so that the result is high amount of products, including unsalable stocks. On the contrary, the uniqueness of production with Pull philosophy lies in the fact, that production starts only when an actual customer demand appears (with detailed specification), which starts procurement and manufacturing processes.

Based on the fundamental differences between the two approaches it is clear the unlike push approach the pull approach results in the realization of the following logistical goals: 1.) shorter lead time; 2.) production is scheduled based on the customer's demands; 3.) only small amount of stock is realized before (raw materials), during (semi-finished products) and after (finished product stock) the production process; 4.) flexible reaction to the changing customer demands; 5.) dedication to continuous improvement; 6.) smaller place for production; 7.) higher utilization of human resources and equipment; 8.) higher productivity, etc.

The Lean production philosophy utilizes the advantages of Pull philosophy, and it is spreading throughout the many sectors, both at production and service companies in automotive industry, electronic industry, offices and health industry as well.

\subsection{Trends in the formation of supply chains}

The rapidly changing market environment and global competition resulted in more complex networks of supply chains. The value chains are globalized, the cooperation between members became more dynamic. The key of success for chains is to understand the customers' demands, and to fulfil it with the highest quality, and at the same time to adapt to the expected changes of market demands.

The competitiveness of each chain originates from the utilization of and synergy between the partners. Although on the global market the supply chains compete as well to fulfil the customer demands with high quality products. Customers choose also between the supply chains by buying a finished product.

Novel supply chain conceptions (Lean-, Agile- and Leagile supply chains) are introduced besides the traditional ones in order to retain the competitiveness of the company $[2,3,4,5]$.

\section{- Lean Supply Chain}

The main goal of the application of „Lean Supply Chains" is to minimize losses in the whole supply chain, by eliminating non value-adding activities, and to improve the processes continuously. These goals are supported by several Lean strategies, such as shortening waiting times and set-up times etc. This results in the realization of production smaller in volume, but more economical and flexible.

This strategy can be applied mostly in case of products with relatively longer lifetime (more than 1-2 years), and the members of the chain work in traditional networked organizational form.

\section{- Agile Supply Chain}

Agile Supply Chain is an other new concept in the formation of supply chains, which are already applied in many sectors. Agility refers to the connection between the finished-product producing company and the customers' market, in other words how fast can the supply chain respond to the customers' demands. The competitiveness and profit of Agile Supply Chain origins from the fast respond of the supply chain to the new challenges of the market.

The produced goods are more custom designed, more unique, produces in smaller quantities, shorter lead time and with reduced cost. This strategy can be applied mostly in case of innovative products with relatively shorter lifetime (maximum 1 year).

\section{- Leagile Supply Chain}

Leagile is a combination of the Lean and the Agile paradigms. Lean supply chain can not quick respond to changing customer demands, thus Leagile supply chain which combine the advantages of Lean production and Agile manufacturing has been used in manufacturing industries.

\section{LEAN PRODUCTION PHILOSOPHY}

Lean thinking focuses on value-added flow and the efficiency of the overall system. The goal is to keep product flowing and add value as much as possible. The focus is on the overall system and synchronizing operations.

Lean manufacturing is a performance-based process used in manufacturing organizations and service sector to increase competitive advantage in an increasingly global market.

Nowadays this philosophy (originating from the Toyota Production System) is applied in many sectors including automotive, electronics, white goods, and consumer products manufacturing, etc.

The focus of the approach is on cost reduction by eliminating non-value added activities [6.].

In today's increasingly global marketplace, many manufacturers are adopting Lean manufacturing practices in order to optimize quality and costs, thereby gaining a competitive advantage.

Advantages of Lean manufacturing [7.]: 1.) production lead times are short; 2.) imbalances in operation timing (bottlenecks) are apparent improvement can focus on bottlenecks; 3.) defects are immediately apparent and the underlying cause can be quickly determined; 4.) constant motivation for improvement - problems have immediate production impact; 5.) operations can quickly shift to a new product (e.g., A to B) without interrupting the flow, each operation makes just what is needed when it is needed; 6.) inventory holding costs are minimized, etc.

\subsection{Lean principles}

The challenge to organizations utilizing Lean manufacturing is to create a culture that will create and sustain long-term commitment from top management through the entire workforce. There are many literatures in topic of Lean production principles and 
application of it $[8,9,10]$.

Lean manufacturing techniques are based on the application of five principles to guide management's actions toward success:

1. Value: The foundation for the value stream that defines what the customer is willing to pay for.

2. The Value Stream: The mapping and identifying of all the specific actions required to eliminate the nonvalue added activities from design concept to customer usage.

3. Flow: The elimination of all process stoppages to make the value stream "flow" without interruptions.

4. Pull: The ability to streamline products and processes from concept through customer usage.

5. Perfection: The ability to advocate doing things right the first time through the application of continuous improvement efforts.

\section{All of processes can be categorized into three groups} [11]:

- value added activities (e.g. manufacturing, assembly, ...),

- required but non-value added activities (e.g. exchange of die),

- wastes are "any element that does not add value, or that the customer is not prepared to pay for" (e.g. over-production, transportation, ...).

The results of the Lean approach are illustrated in Fig. 1. In case of Lean manufacturing the ratio of the value adding and non-value adding activities will be improved compared to traditional manufacturing by elimination of wastes in processes.

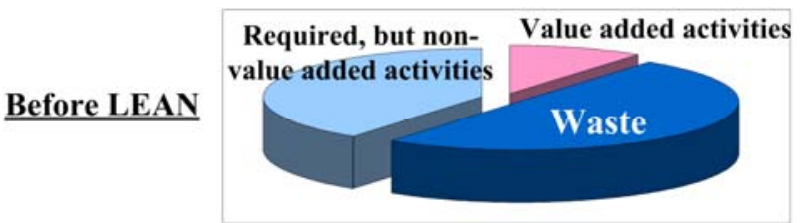

After LEAN

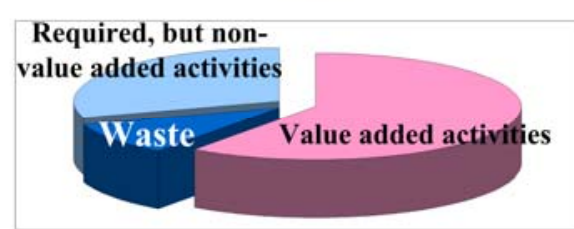

Fig. 1. Traditional manufacturing vs. Lean manufacturing

\subsection{Lean wastes}

Seven types of wastes [12] can be identified in processes (Fig. 2.).

1. Over production - Producing more final products than is needed or before it is needed for the customer is a fundamental waste in Lean manufacturing.

2. Waiting - Worker or machine is waiting for material or information. Material waiting is not material flowing through value-added operations.

3. Motion - Any unnecessary motion that does not add value to the product is waste.

4. Transportation - Moving material does not enhance the value of the product to the customer.

5. Inventories - Material sits taking up space, costing money, and potentially being damaged. Due to stocks problems are not visible.

6. Over- processing - Extra processing not essential to value-added from the customer point of view is waste.

7. Producing defective products - Defective products impede material flow and lead to wasteful handling, time, and effort.

8. Other additional wastes - Underutilized worker creativity and resource, application of non adequate equipments and systems, wasted energy and water, damage of environment.

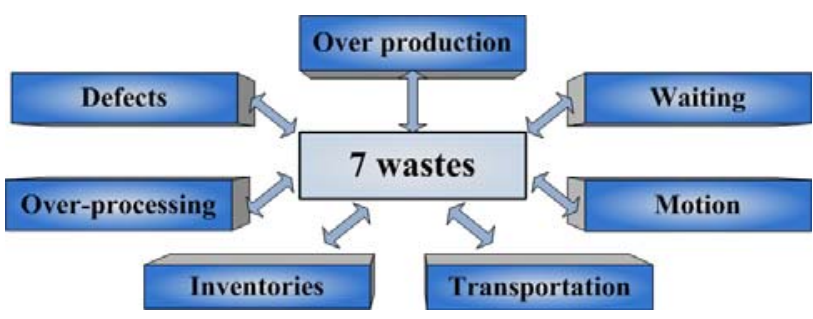

Fig. 2. Seven types of wastes

These wastes are readily apparent in every manufacturing facility in the business world. Companies who identify, manage, and minimize these wastes are able to succeed the best in the very competitive marketplace.

A central element of the Lean philosophy is the systematic elimination of unneeded resources, or waste.

The basics of Lean manufacturing employ continuous improvement processes to focus on the elimination of waste or non-value added steps within an organization and production.

\section{MAIN TOOLS AND TECHNICS OF LEAN MANUFACTURING}

Lean tools and techniques focus on certain aspects and areas of the manufacturing process in order to help reduce costs and improve efficiencies of the processes at the company.

The main tools and techniques of Lean manufacturing $[6,10,13,14]$ are for example Value Stream Mapping, JIT, One-piece flow, Takt-time analysis, Heijunka, Single Minute Exchange of Dies (SMED), Jidoka, Pull system, Kanban, Supermarket, Kaizen, Standardised processes, 5S, Total Productive Maintenance (TPM), 6 $\sigma$, Cell design and layout for flow (Cellular production, U-shaped cells), Work group team error proofing, Zero defects (ZD), Station and operation process control, Error proofing (poke-yoke), Balanced flow-, Synchronous flow, Mixed flow lines, etc.

The application of Lean production philosophy can result the improvement of the following Key Performance Indicators (KPI): shorter lead times, shorter set up times, smaller stocks, increase of free production area, increased quality of products, general increase of the efficiency of production, increase of productivity.

The Lean manufacturing and a Lean enterprise mean that the company is focused on supplying exactly 
what the customer wants, in the form they want it in, free of defects, at the exact time that they want it, with minimal waste in the process.

\section{CONCLUSION}

Globalization, changing economic environment and customers' demands and the ever increasing competition in the market results in application of new manufacturing technologies, methods. The paper showed these global production tendencies.

Novel supply chain concepts are formed besides the traditional ones in order to retain the competitiveness of the supply chains and the supply chain members. In this study these supply chain conceptions (Lean-, Agile-, Leagile Supply Chains) were introduced.

In a competitive market the manufacturing companies have to produce cost effective products which can be realized by minimized production cost and higher effectiveness. Recently more and more companies apply the Lean production philosophy which focuses on cost reduction and productivity improvement by eliminating non-value added activities.

In this study the author defined the essence and characteristics of the Lean philosophy and emphasized the importance of application of Lean manufacturing, techniques and tools. Nowadays this philosophy is applied in many sectors including automotive, electronics, etc. in order to optimize productivity and costs.

Based on the above mentioned facts, it was confirmed that the Lean manufacturing philosophy is an effective tool for production process improvement.

\section{REFERENCES}

[1] Kovács, Gy.: Lean production philosophy, textbook, (in Hungarian), University of Miskolc, Institute of Logistics, 2014.

[2] Vonderembse, M. A. et al.: Designing supply chains: Towards theory development, International Journal of Production Economics, 100, p.p. 223238, 2006.

[3] Naylor, J. B., Naim, M. M., Berry D.: Leagility: Integrating the lean and agile manufacturing paradigms in the total supply chain, International Journal of Production Economics, 62, p.p. 107118, 1999.

[4] Schönsleben, P.: With agility and adequate partnership strategies towards effective logistics networks, Computers in Industry, 42 (1), p.p.: 3342, 2000.

[5] Agarwal, A., Shankar, R., Tiwari M. K.: Modeling the metrics of lean, agile and leagile supply chain: An ANP-based approach, European Journal of Operational Research - Production, Manufacturing and Logistics, 173, p.p.: 211-225, 2006.

[6] Womack, J. P., Jones, D. T., Roos, D.: The Machine that Changed the World: The Story of Lean Production, Harper Collins Publishers, New York, 1990.

[7] Kovács, Gy.: Productivity improvement by lean manufacturing philosophy, Advanced Logistic
Systems: Theory and Practice, 6 (1), p.p. 9-16, 2012.

[8] Fawaz, A. A., Jayant, R.: Analyzing the benefits of lean manufacturing and value stream mapping via simulation: A process sector case study, International Journal of Production Economics, 107, p.p. 223-236, 2007.

[9] Fullerton, R. R., McWatters, C. S., Fawson, C.: An examination of the relation ships between JIT and financial performance, Journal of Operations Management, 21 (4), p.p. 383-404, 2003.

[10] Womack, J. P., Jones, D. T.: Lean Thinking: Banish Waste and Create Wealth in Your Corporation, Simon \& Schuster, New York, 1996.

[11]Liker, J. K., Lamb, T.: Lean manufacturing principles guide DRAFT, Version 0.5, University of Michigan, 2000.

[12] McLachlin, R.: Management in initiatives and justin-time manufacturing, Journal of Operations Management, 15 (4), p.p. 271-292, 1997.

[13] Holweg, M.: The genealogy of lean production, Journal of Operations Management, 25 (2), p.p. 420-437, 2007.

[14] Senderská, K., Lešková, A., Mareš, A.: Design characteristics of manual assembly workstation system in the lean production system, Jurnal of Production Engineering, 16 (1), p.p. 87-92, 2013.

\section{ACKNOWLEDGEMENT}

This project has received funding from the European Union's Horizon 2020 research and innovation programme under grant agreement No 691942”.

Author: György Kovács PhD, Assoc. Professor, University of Miskolc, Faculty of Mechanical Engineering and Informatics, Institute of Logistics, Miskolc-Egyetemváros, Miskolc, Hungary

E-mail: altkovac@uni-miskolc.hu 